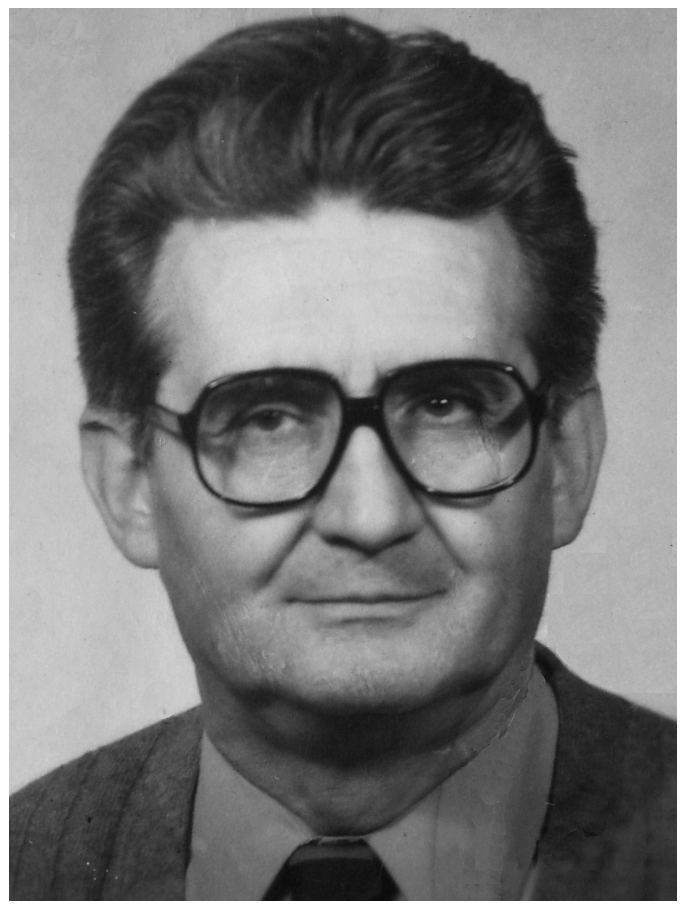

\title{
Farewell to István Zoltán Nagy
}

(1928-2017)

\section{Tibor KeCSKeméti}

Department of Palaeontology and Geology, Hungarian Natural History Museum, H-1083 Budapest, Ludovika tér 2, Hungary.E-mail: kecskemeti.tibor@gmail.com

István Zoltán Nagy passed away on the 26th of March 2017 at 90 years of age. Nagy was an emeritus curator in the Department of Palaeontology and Geology at the Hungarian Natural History Museum, Budapest. He was born on the 23rd of February 1928 in Erdökövesd, Hungary. He studied at the elementary school in Ivád, a small village where his father was a cantor-teacher and director of the school, and his mother also was a teacher. 
Nagy completed school at the Training College of Eger, from where he obtained a degree in teaching and then worked in this role for a short period in Tiszanána. However, he was interested in nature from an early age, and later in Natural Sciences, especially zoology, and palaeontology. He even won an award in the latter field based on his college dissertation.

Nagy studied biology and geography at Eötvös Loránd University in Budapest from 1949, where he took courses with Miklós Kretzoi on the development of organic life. He read a lot about palaeontology throughout this period and his irrepressible love of science took him to libraries for the chance to spend all day reading scientific books and publications. He bought scientific books from his small scholarship money, and we, his classmates, also gained experience from his wide professional knowledge at seminars. I can attest to his awareness in palaeontology, phylogenetics, and evolution as we were colleagues at the university; he often gave us scientific presentations in these topics in the breaks between lectures and we were all impressed by his knowledge. Indeed, by this time, his professors had got to know him and his talent and so they gave him more opportunities; once he gained his university degree in Biology and Geography, Jenő Noszky jr. offered for him a job at the Hungarian Geological Institute in Budapest. Nagy began to work there as a palaeontologist safe in the knowledge that his biological background would be very useful to his research in this area.

At the Institute, Nagy worked in the Palaeontology Department where Miklós Kretzoi, renowned palaeontologist throughout Europe, became his group leader and later his mentor. Kretzoi provided Nagy with a great deal of advice, guidance, and ideas for new research topics. Nagy was able to learn a lot from the intense intellectual and scientific atmosphere of this Department, especially from palaeontologists like András Kubacska Tasnádi and Ferenc Bartha.

At this time, Nagy began to study the Jurassic flora of the Mecsek Mountains as well as the Cretaceous ammonite fauna of the Gerecse Mountains. A number of his papers appeared in the Földtani Közlöny; many of these are still valid today and are often cited. At the end of 1950s he got his PhD degree. However, when the Institute got new leadership, people tried to expropriate and take over Nagy's results on ammonites so he applied for candidate status in the Developmental Biology Department of the Medical University, Budapest, and then later (in 1967) moved to the Department of Palaeontology and Geology of the Hungarian Natural History Museum, Budapest. At this Department he was able to obtain his C.Sc. degree and he continued to work for the museum until his retirement.

The scientific work of István Zoltán Nagy evolved during his employment at the Museum; he continued to study the Cretaceous ammonites of Gerecse, and over the course of this work presented several new taxonomic, stratigraphical, phylogenetic, and palaeobiological conclusions. He communicated his results at 
scientific meetings of the Hungarian Geological Society, as well as in scientific journals. At the same time, as the Mesozoic curator at the Museum, Nagy reorganized the scientific collection using modern phylogenetic principles and had a significant role in both writing and managing the permanent and temporary palaeontology exhibitions.

Nagy was also very active in promoting the public understanding of science; he publicised Geosciences in particular extensively with his talks and publications, and was a regular contributor to the Természet Világa magazine. Over a ten year period, he was also one of the permanent editors, experts, and sometimes a jury member for student Earth Science competitions at the József Szabó Geological Technical School in Tatabánya.

The excellent research activities of the Department of Palaeontology at the Museum at this time, coupled with his own scientific work meant that István Zoltán Nagy was well integrated within the community by this stage of his career. He took part in several common museum programs and because of his useful and successful scientific and community engagement, he was commissioned by Vilmos Székessy the chief director of the Hungarian Natural History Museum, with scientific secretary activities. For a couple of years he also edited the Fragmenta Mineralogica et Palaeontologica, the journal of Earth Sciences departments of the Museum. In particular, it is key to emphasise Nagy's strong interest in the history of science; he mostly studied museum history, and also published a series on the Natural History Museums of Europe.

Nagy's precise research was characterised by his wide knowledge of the scientific literature, as well as his thorough research and ability to adapt to new trends. He also placed a lot of emphasis on evolutionary trends; he had a good sense to see even the tiniest differences between subspecies. Apart from these, he had excellent debating skills, too. His capacity to generate an abundance of new and significant results made him an acknowledged researcher within his specialist field.

Subsequent to his retirement, Nagy continued with a modest level of work within his beloved profession. However, as he advanced in age, he became sick and so was unable to regularly participate in scientific circles but nevertheless maintained his interest in research. He had a rich library which contained more than 10,000 valuable books. When I was fortunate to visit him, also found him with a book in his hand and he welcomed me with reminiscences about our years together at the university. Meeting with Nagy was always enjoyable and uplifting.

István Zoltán Nagy was an introverted man who was kind and polite with a caustic sense of humour. His relationships were always characterised by his helpfulness and honesty. Nagy was deeply in love with his wife, the chemist Margit Melles, who he met when working at the Hungarian Geological Institute. She 
was a radiologist at the Institute, and later a Chemistry teacher at the Geological Technical School. They shared a love for similar research, sometimes collaborating. Their common interests led to a devotional love for one another and a harmonious marriage. It is very sad that after 58 years together his death was the end of this relationship.

\section{Requiescat in pace!}

Acknowledgement - English translation of the text was prepared by Eszter Hankó.

\section{István Zoltán Nagy’s scientific papers (probably incomplete list)}

NAGY I. Z. 1958: Kiegészítő adatok a mecseki jura flórájához. (Complementary data on the Jurassic flora of the Mecsek-Mountains.) - Földtani Közlöny 88: 128-129.

NAGY I. Z. 1958: Teudopsis subacuta n. sp. a mecseki liászból. (Teudopsis subacuta n. sp. aus dem Mecseker Lias.) - Földtani Közlöny 88: 242.

NAGY I.Z.1959: Neocalamites és ?Neocalamostachys a mecseki liászból. (Neocalamites und ?Neocalamostachys aus dem Lias im Mecsek-Gebirge, Süd-Ungarn.) - Földtani Közlöny 89: 431-432.

NAGY I. Z. 1963: Phylloceras thetys (d'Orbigny) szelekciós fajfejlődési sora a gerecsei alsókréta rétegekböl. (The succession of the selective evolution of Phylloceras thetys (d'Orbigny) from the Lower Cretaceous beds in the Gerecse Mts.) - Földtani Közlöny 93: 481-485.

NAGY I. Z. 1964: Palichnológiai adatok a gerecsei alsókréta időszaki rétegekből. (Palichnological data from Lower Cretaceous beds in the Gerecse Mts.) - Földtani Közlöny 94: 138-140.

NAGY I. Z. 1964: Rendellenes házú alsókréta ammoniteszek a Gerecséből. (Lower Cretaceous Ammonites with irregular shells from the Gerecse Mts.) - Földtani Közlöny 94: 141-142.

NAGY I. Z. 1965: Egy Szabó József kézirat a Társulat „hőskorából”. [József Szabó’s manuscript from the beginning of the Society.] - Földtani Közlöny 95: 445-447.

NAGy I. Z. 1967: Unterkretazische Cephalopoden aus dem Gerecse-Gebirge I. - Annales historiconaturales Musei nationalis hungarici 59: 53-80.

NAGY I. Z. 1967: Embryológiai és hisztokémiai vizsgálatok kétéltűek chorda dorsalisán. (Embryological and histochemical investigations on the Chorda dorsalis of Amphibia.) - Állattani Közlemények 54: 115-119.

NAGY I. Z. 1967: A gerinchúr (Chorda dorsalis) származástani jelentősége. [Evolutionary significance of Chorda dorsalis.] - Öslénytani Viták 9: 16-25.

NAGY I. Z. 1967: Az ontogenezis filogéniai vonatkozásai. [Phylogenetic relations of ontogeny.] Öslénytani Viták 10: 35-41.

NAGY I. Z. 1968: Alsóbarrémi korú Ancyloceras és Stomahamites (Cephalopoda, Ammonoidea). (Ancyloceras and Stomahamites (Cephalopoda, Ammonoidea) of Lower Barremian age.) Földtani Közlöny 98: 281-284.

NAGY I. Z. 1968: Fejlődéstani és hisztokémiai vizsgálatok madár és emlősembryók gerinchúrján. (Embryological and histochemical examinations on the Chorda dorsalis of bird and mammal embryos.) - Állattani Közlemények 55: 75-79. 
NAGY I. Z. 1968: Unterkretazische Cephalopoden aus dem Gerecse-Gebirge II. - Annales historiconaturales Musei nationalis hungarici 60: 41-59.

Nagy I. Z. 1969: Pulchelliidák (Cephalopoda, Ammonoidea) a gerecsei alsókrétából. (Pulchelliidae (Cephalopoda, Ammonoidea) from the Lower Cretaceous of the Gerecse Mountains, Hungary.) - Földtani Közlöny 99: 206-210.

NAGY I. Z. 1969: Őslénytani adatok a gerecsei alsókrétából. (Paleontological data from the Lower Creataceous of the Gerecse Mountains, Hungary.) - Földtani Közlöny 99: 211-214.

NaGY I. Z. 1969: Megjegyzések a mono- és polyphylia kérdéséhez. [Comments on mono- and polyphyly.] - Öslénytani Viták 11:3-11.

NAGY I. Z. 1969: Data to the comparative histology and the evolutional significance of the Chorda dorsalis. - Fragmenta Mineralogica et Paleontologica 1: 111-158.

NAGY I. Z. 1969: Hisztokémiai adatok a Branchiostoma lancolatum (Pallas) Chorda dorsalisának alaktanához. (Histochemical data to the morphology of the Chorda dorsalis of Branchiostoma lanceolatum (Pallas).) - Állattani Közlemények 56: 107-109.

Nagy I. Z. 1970: Lower Liassic Molluscs from the Mts. Mecsek, Hungary. - Annales historico-naturales Musei nationalis hungarici 62: 85-98.

NAGY I. Z. 1970: Adatok a gerecsei alsókréta Cephalopoda faunájához. (Contributions to the Lower Cretaceous Cephalopoda fauna of the Gerecse Mountains, Komárom County, Hungary.) Földtani Közlöny 100: 211-214.

NAGY I. Z. 1971: Lower Cretaceous Cephalopods from Mts. Bakony, Hungary. - Annales historiconaturales Musei nationalis hungarici 63: 13-36.

NAGy I. Z. 1973: A vraconni alemelet és kutatásának története Magyarországon. (The Vraconnian Substage and the History of its Study in Hungary.) - Fragmenta Mineralogica et Paleontologica 4: 81-107.

NAGY I. Z. 1978: In memoriam Dr. Ilona Csepreghy, née Meznerics (1906-1977). - Annales historico-naturales Musei nationalis hungarici 70: 5-8.

NAGY I. Z. 1980: Kubinyi Ferenc, a természettudós. [Ferenc Kubinyi, the naturalist.] - Nógrád Megyei Múzeumok Évkönyve 6: 109-119.

NAGY I. Z. 1981: Unterkretazische Cephalopoden aus der „Marmorgrube” bei Zirc (Bakony-Gebirge, Ungarn). - Annales historico-naturales Musei nationalis hungarici 73: 69-77.

NAGY I. Z. 1981: Die Barreme-Stufe des Berzsek-Berges (Gerecse-Gebirge, Ungarn). - Fragmenta Mineralogica et Paleontologica 10: 27-29.

NAGY I. Z. 1982: Ősi típusú ammonoidák (Flickiidae) a bakonyi középső krétából. (Ancient-type ammonoids, Flickiidae, from the Middle Cretaceous of the Bakony Mts.) - Öslénytani Viták 28: 69-77.

NAgY I. Z. 1986: A Turrilitidae (Cephalopoda, Ammonoidea) néhány nomenclaturai kérdése és a család filogenetikai-rétegtani viszonyai. (Some nomenclatural problems of Turrilitidae (Cephalopoda, Ammonoidea) and the phylogenetical and stratigraphical relationships of the family.) - Öslénytani Viták 33: 53-61.

NAGY I. Z. 1986: A heteromorph ammonoideák életmód-hipotézisének újabb adatai. (New data to the hypothetical mode of life of heteromorph ammonoids.) - Öslénytani Viták 33: 62-71.

NAGY I. Z. 1987: Dezső Laczkó (1860-1932). - Annals of the History of Hungarian Geology, Special Issue: $115-117$.

NAGY I. Z. 1987: Fossile fish remains from the Monte Bolca locality (Italy) in the Museum of Natural History (Budapest). - Annals of the History of Hungarian Geology, Special Issue: 309-315.

NAGY I. Z. 1987: Ernst Haeckel természettudományos jelentősége. (Ernst Haeckel's importance in natural history.) - Biológia 33: 153-159. 
NAgy I. Z. \& Kecs Keméti T. 1987: Palaeontological collections of the Hungarian Natural History Museum (Budapest). - Annals of the History of Hungarian Geology, Special Issue: 151-159.

Nagy I. Z. \& Kecskeméti T. 1991: The Paleozoological Collection of the Hungarian Natural History Museum. - Annals of the History of Hungarian Geology, Special Issue 3: 67-86.

NaGy I. Z. \& Kecskeméti T. 1994: A Magyar Természettudományi Múzeum ősállattani gyüjteménye (Föld- és Öslénytár). (The paleozoological collection of the Department of Geology and Paleontology of the Hungarian Natural History Museum.) - In: KeCs Keméti T. \& PAPP G. (szerk.): Földünk hazai kincsesházai. Tanulmányok a magyarországi földtudományi gyüjtemények történetéröl, pp. 51-67. 